\title{
Stability-Indicating HPLC Determination of Pramipexole dihydrochloride in Bulk Drug and Pharmaceutical Dosage Form
}

\author{
Vedavati M. Panditrao, Aniket P. Sarkate, Jaiprakash N. Sangshetti, Pravin S. Wakte and \\ Devanand B. Shinde*
}

\author{
Department of Chemical Technology, Dr. Babasaheb Ambedkar Marathwada University, \\ 431004 Aurangabad-MS, India
}

\begin{abstract}
Um novo método de cromatografia líquida de alta eficiência, indicativo de estabilidade foi desenvolvido e validado para determinação quantitativa de dicloridrato de pramipexol em medicamentos a granel e em doses farmacêuticas na presença de produtos de degradação. Um método de HPLC em fase reversa isocrática foi desenvolvido para separar a droga dos produtos de degradação, usando-se previamente uma coluna cromatográfica Ace5-C18 (250×4,6 mm, $5 \mu \mathrm{m})$ e $10 \mathrm{mmol} \mathrm{L}^{-1}$ de acetato de amônia e acetonitrila (75:25 v/v) como fase móvel. A detecção ocorreu num comprimento de onda de $260 \mathrm{~nm}$. O pramipexol foi submetido a condições extremas de hidrólise (ácidos, bases), oxidação, fotólise e degradação térmica. Foi observada degradação para pramipexol em base, em ácido e em $30 \% \mathrm{H}_{2} \mathrm{O}_{2}$. Em outras condições extremas, a droga mostrou-se estável. Os produtos de degradação foram bem resolvidos a partir do pico principal. A porcentagem de recuperação do pramipexol foi de 99,87 a 99,98\% em doses farmacêuticas. O método desenvolvido foi validado com relação à linearidade, exatidão (recuperação), precisão, adequação do sistema, especificidade e robustez. Os estudos de degradação forçada mostraram a estabilidade, indicando o poder do método.
\end{abstract}

A novel stability-indicating high-performance liquid chromatographic assay method was developed and validated for quantitative determination of pramipexole dihydrochloride in bulk drugs and in pharmaceutical dosage form in the presence of degradation products. An isocratic, reversed phase HPLC method was developed to separate the drug from the degradation products, using an Ace5-C18 $(250 \times 4.6 \mathrm{~mm}, 5 \mu \mathrm{m})$ advance chromatography column, and $10 \mathrm{mmol} \mathrm{L}{ }^{-1}$ ammonium acetate and acetonitrile $(75: 25 \mathrm{v} / \mathrm{v})$ as a mobile phase. The detection was carried out at a wavelength of $260 \mathrm{~nm}$. The pramipexole was subjected to stress conditions of hydrolysis (acid, base), oxidation, photolysis and thermal degradation. Degradation was observed for pramipexole in base, in acid and in $30 \% \mathrm{H}_{2} \mathrm{O}_{2}$. The drug was found to be stable in the other stress conditions attempted. The degradation products were well resolved from the main peak. The percentage recovery of pramipexole was from (99.87 to $99.98 \%$ ) in the pharmaceutical dosage form. The developed method was validated with respect to linearity, accuracy (recovery), precision, system suitability, specificity and robustness. The forced degradation studies prove the stability indicating power of the method.

Keywords: pramipexole, HPLC, validation, stability, degradation

\section{Introduction}

Pramipexole is a synthetic amino-benzthiazole derivative. Chemically it is $\mathrm{N}^{6}$-propyl-4,5,6,7-tetrahydrobenzo[d]thiazole-2,6-diamine (Figure 1).

Pramipexole is a dopaminergic agonist which is effective in the Parkinson's disease. It is a selective and specific full dopaminergic receptor agonist with high

*e-mail: dbsaniket09@ rediffmail.com affinity and selectivity for the D2 receptor subfamily, and particularly the D3 receptor subtype. Pramipexole has good oral bioavailability. Absolute bioavailability is greater than $90 \%$ indicating that pramipexole is well absorbed and<smiles>CCCNC1CCc2nc(N)sc2C1</smiles>

Figure 1. Pramipexole. 
undergoes little presystemic metabolism. Food does not affect the extent of absorption..$^{1-3}$

This drug has been approved by United States Food and Drug Administration (USFDA) for the treatment of restless leg syndrome in November 2006. It was already approved by the European Union in April 2006. ${ }^{4}$ A literature survey reveals a liquid chromatography mass spectroscopy (LCMS) method for determination of pramipexole in human plasma. ${ }^{5}$ The high performance liquid chromatography (HPLC) method for pramipexole is also reported for determination of the drug in the tablet dosage form. ${ }^{6}$

The determination of the dissociation constant for the pramipexole is also done using chromatography techniques. ${ }^{7}$ HPLC is a versatile technique. According to current good manufacturing practices, all drugs must be tested with a stability-indicating assay method before release. Till date, no stability-indicating HPLC assay method for the determination of pramipexole is available in the literature. It was felt necessary to develop a stability indicating liquid chromatography (LC) method for the determination of pramipexole as bulk drug and pharmaceutical dosage form and separate the drugs from the degradation products under the International Conference on Harmonization (ICH) suggested conditions (hydrolysis, oxidations, photolysis and thermal stress). ${ }^{8}{ }^{89}$ Therefore, the aim of the present study was to develop and validate a stability-indicating HPLC assay method for pramipexole as bulk drug and in pharmaceutical dosage form as per ICH guidelines. ${ }^{9}$

\section{Experimental}

\section{Material and reagents}

Pramipexole dihydrochloride bulk drug (purity 99.8) and tablet pramipex $(0.25 \mathrm{mg})$ were obtained from Sun Pharmaceuticals (Mumbai, India). Acetonitrile, methanol, hydrochloric acid and sodium hydroxide pellets were obtained from Rankem Laboratories India. Ammonium acetate was obtained from Merck Specialities Private Ltd. Hydrogen peroxide is obtained from Fischer Scientific, India. All chemicals used are of HPLC grade. Milli-QWater was used throughout the experiment.

\section{Chromatographic conditions}

The HPLC system used was a Jasco (2000 series) system equipped with a photodiode array detector. A chromatographic column of $250 \mathrm{~mm}$ length and internal diameter of $4.6 \mathrm{~mm}$ filled with octadecyl silane Ace5-C18
(Advance Chromatography Technology, USA) stationary phase with particle size $5 \mu \mathrm{m}$ were used. The instrumental setting was at a flow rate of $1 \mathrm{~mL} \mathrm{~min}{ }^{-1}$. The injection volume was $20 \mu \mathrm{L}$. The detection wavelength was $260 \mathrm{~nm}$.

\section{Mobile phase}

The mobile phase consisted of buffer and acetonitrile in the ratio $(75: 25 \mathrm{v} / \mathrm{v})$. The buffer used in the mobile phase contained $10 \mathrm{mmol} \mathrm{L}^{-1}$ of ammonium acetate in doubledistilled water. The mobile phase was premixed and filtered through a $0.45 \mu$ nylon filter and degassed.

\section{Preparation of standard stock solutions}

All solutions were prepared on a weight basis and solution concentrations were also measured on weight basis to avoid the use of an internal standard. Standard solution of pramipexole was prepared by dissolving the drugs in the diluents and diluting them to the desired concentration. Diluent A was composed of methanol and diluent B was composed of water and acetonitrile in the ratios of $(75: 25 \mathrm{v} / \mathrm{v})$. Approximately $5 \mathrm{mg}$ of pramipexole was accurately weighed, transferred in a $50 \mathrm{~mL}$ volumetric flask, dissolved and diluted to $50 \mathrm{~mL}$ with the diluent A. From these stock solutions $2 \mathrm{~mL}$ of pramipexole standard solution were transferred in a $10 \mathrm{~mL}$ volumetric flask and diluted with diluent $\mathrm{B}$. This final solution contained $20 \mu \mathrm{g} \mathrm{mL}^{-1}$ of pramipexole.

\section{Sample solution (tablets)}

Ten tablets of pramipex $(0.25 \mathrm{mg})$ were finely ground using agate mortar and pestle. The ground material, which was equivalent to $2.5 \mathrm{mg}$ of the active pharmaceutical ingredient, was extracted into diluent $\mathrm{A}$ in a $25 \mathrm{~mL}$ volumetric flask by vortex mixing followed by ultra sonication. Take $2 \mathrm{~mL}$ of it and dilute it to $10 \mathrm{~mL}$ with diluent $\mathrm{B}$. The solution was filtered through a $0.45 \mu$ nylon filter and an appropriate concentration of sample ( $20 \mu \mathrm{g} \mathrm{mL}-1$ assay concentration) was prepared at the time of analysis.

\section{Procedure for forced degradation study}

Stability testing is an important part of the process of drug product development. The purpose of stability testing is to provide evidence of how the quality of a drug substance or drug product varies with time under a variety of environmental conditions, for example temperature, humidity, and light and enables recommendation of storage conditions, retest periods, and shelf life to be established. The 
two main aspects of drug product that play an important role in shelf-life determination are assay of the active drug and the degradation products generated during stability studies.

\section{Preparation of sample solution}

\section{Acidic degradation}

$5 \mathrm{mg}$ drug was dissolved in the $5 \mathrm{~mL}$ of the diluent $\mathrm{A}$. $50 \mathrm{~mL}$ of the $3 \mathrm{~mol} \mathrm{~L}^{-1}$ hydrochloric acid was added to it. The solution was kept for $1 \mathrm{~h} .10 \mathrm{~mL}$ of solution was taken from it and neutralized with $3 \mathrm{~mol} \mathrm{~L}^{-1}$ sodium hydroxide. Then the solution was diluted with diluent $\mathrm{B}$ to prepare working solution of $20 \mu \mathrm{g} \mathrm{mL}^{-1}$ ( $\mathrm{pH}$ of solution was 2.3 ).

\section{Alkaline degradation}

$5 \mathrm{mg}$ drug was dissolved in the $5 \mathrm{~mL}$ of the diluent $\mathrm{A}$. $50 \mathrm{~mL}$ of the $0.5 \mathrm{~mol} \mathrm{~L}^{-1}$ sodium hydroxide was added to it. The solution was kept for $1 \mathrm{~h} .10 \mathrm{~mL}$ of solution was taken from it and neutralized with $0.5 \mathrm{~mol} \mathrm{~L}^{-1}$ hydrochloric acid. Then the solution was diluted with diluent $\mathrm{B}$ to prepare working solution of $20 \mu \mathrm{g} \mathrm{mL}^{-1}$ ( $\mathrm{pH}$ of solution was 14).

\section{Oxidative degradation}

$5 \mathrm{mg}$ drug was dissolved in $5 \mathrm{~mL}$ of diluent $\mathrm{A}$ and $50 \mathrm{~mL}$ of $30 \% \mathrm{H}_{2} \mathrm{O}_{2}$ was added. The solution was kept for $4 \mathrm{~h}$. Then the solution was diluted with diluent $\mathrm{B}$ to prepare working solution of $20 \mu \mathrm{g} \mathrm{mL} \mathrm{m}^{-1}$.

\section{Thermal degradation}

$10 \mathrm{mg}$ drug was kept in the hot air oven for $48 \mathrm{~h}$ at $100{ }^{\circ} \mathrm{C}$ temperature. Then the working solution was prepared using diluent $\mathrm{A}$ and diluent $\mathrm{B}$.

\section{Photo degradation}

$10 \mathrm{mg}$ of drug is exposed to the short wavelength $(254 \mathrm{~nm})$ and long wavelength $(366 \mathrm{~nm}) \mathrm{UV}$ light for $48 \mathrm{~h}$. Then the working solution was prepared using diluent $\mathrm{A}$ and diluent $\mathrm{B}$.

\section{Specificity}

Specificity is the ability of the method to assess unequivocally the analyte in the presence of components, which may be expected to be present. Typically, these might include degradation products, matrix etc. ${ }^{9}$ The specificity of the developed HPLC method for pramipexole was carried out in the presence of its degradation products. Stress studies were performed for pramipexole bulk drug to provide an indication of the stability indicating property and specificity of the proposed method. Intentional degradation was attempted to stress conditions exposing it with acid (3 mol L-1 hydrochloric acid), alkali $\left(0.5 \mathrm{~mol} \mathrm{~L}^{-1} \mathrm{NaOH}\right)$, hydrogen peroxide $(30 \%)$, heat $\left(100{ }^{\circ} \mathrm{C}\right)$ and UV light (254 and $366 \mathrm{~nm}$ wavelength) to evaluate the ability of the proposed method to separate pramipexole from its degradation products. For light and heat study, the study period was $48 \mathrm{~h}$ whereas for acid and base $1 \mathrm{~h}$ and for oxidation $4 \mathrm{~h}$. Peak purity test for pramipexole was by using PDA detector in stress samples.

\section{Results and Discussion}

\section{Optimization of chromatographic conditions}

The primary target in developing this stability indicating HPLC method is to achieve the resolution between pramipexole and its degradation products. To achieve the separation of degradation products we used a stationary phase $\mathrm{C}-18$ and combination of mobile phase $10 \mathrm{mmol} \mathrm{L}^{-1}$ ammonium acetate with acetonitrile. The separation of the degradation product and pramipexole was achieved on Ace5 octadecyl silane C-18 stationary phase and $10 \mathrm{mmol} \mathrm{L}^{-1}$ ammonium acetate and acetonitrile $(75: 25 \mathrm{v} / \mathrm{v})$ as a mobile phase. The tailing factor obtained was less than two and retention time was about $3.3 \mathrm{~min}$ for the main peak and less than 4 min for the degradation products, which would reduce the total run time and ultimately increase the productivity thus reducing the cost of analysis per sample. Forced degradation study showed the method is highly specific and entire degradation products were well resolved from the main peak. The developed method was found to be specific and method was validated as per international guidelines.

\section{Result of forced degradation experiments}

Degradation was not observed for pramipexole samples during stress conditions like heat, UV and light, except in base, acid and oxidation. Pramipexole was degraded into acid (Figure 2), base (Figure 3) and oxidation (Figure 4) and forms polar impurities.

In the acidic condition $7.54 \%$, in the basic condition $4.88 \%$ after $1 \mathrm{~h}$ and in the oxidative condition $58.70 \%$ after $4 \mathrm{~h}$, degradation was observed for pramipexole. Peak purity results greater than 990 indicate that the pramipexole peak is homogeneous in all stress conditions tested. The unaffected assay of pramipexole dihydrochloride in the tablets confirms the stability indicating power of the method (Table 1).

\section{Determination of active ingredients in tablets}

The contents of drug in tablets were determined by the proposed method using the calibration curve. 


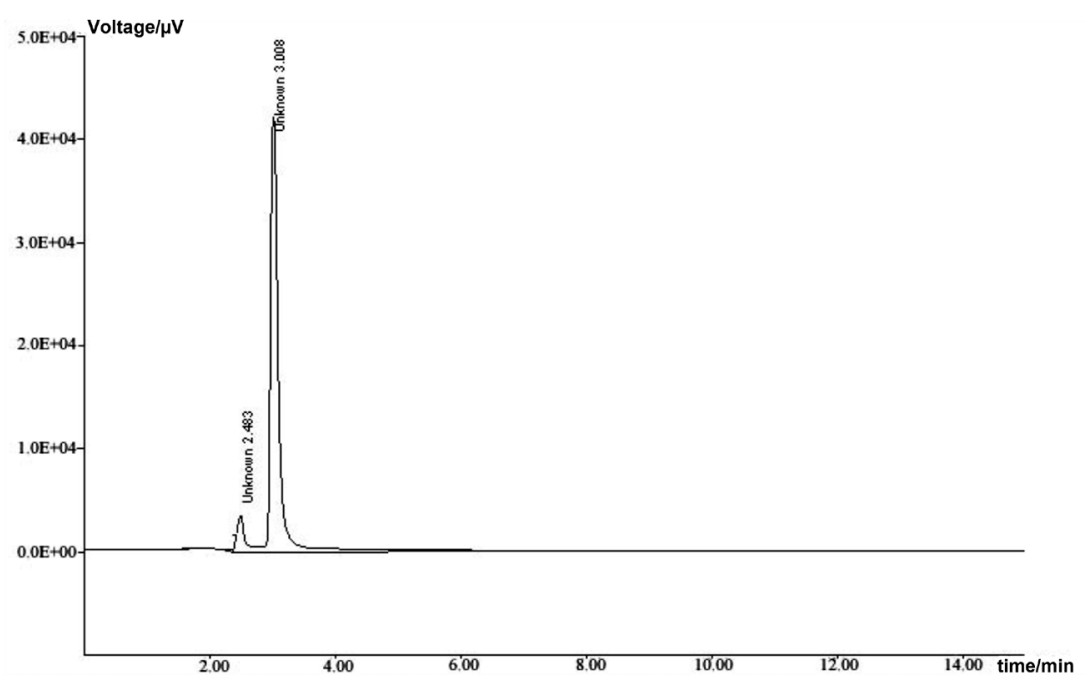

Figure 2. Chromatogram of pramipexole in acid degradation (acid degraded product (2.4 min) and pramipexole (3.2 min)). Concentration of pramipexole injected was $20 \mu \mathrm{g} \mathrm{mL}^{-1}$.

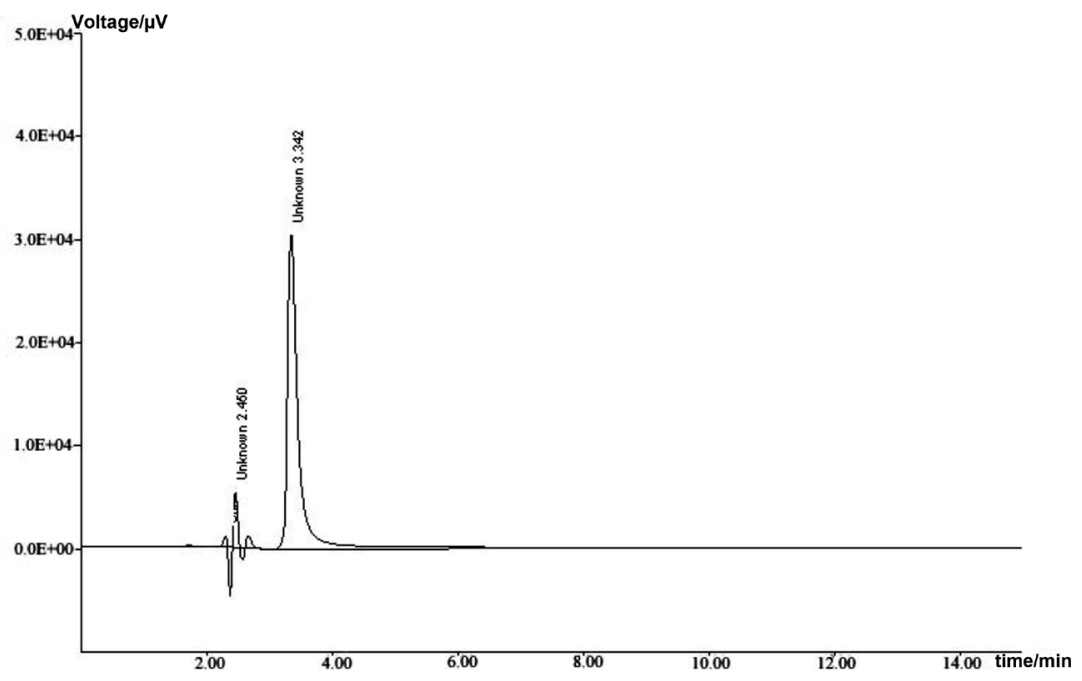

Figure 3. Chromatogram of pramipexole in base degradation (base degraded product (2.4 min) and pramipexole (3.2 $\mathrm{min})$ ).

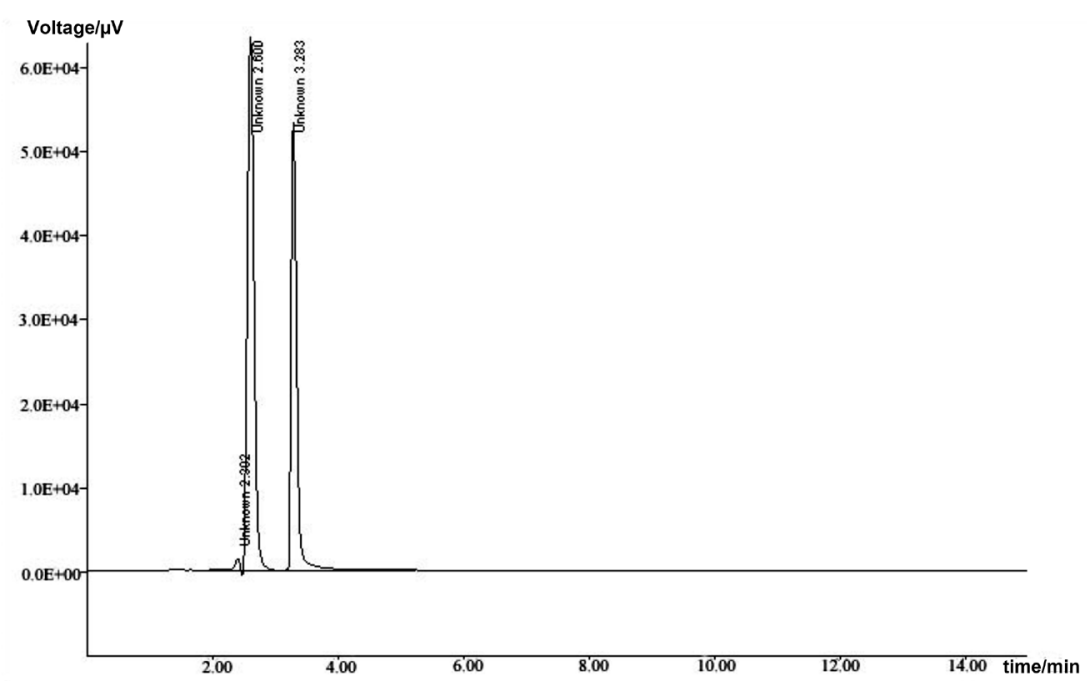

Figure 4. Chromatogram of pramipexole in oxidative degradation (oxidative degraded product (2.4 min) and pramipexole (3.2 min)). 
Table 1. Summary of forced degradation results

\begin{tabular}{lccc}
\hline Stress conditions & time / h & Assay of active substance & Degradation / $(\%)$ \\
\hline Acid hydrolysis $\left(3 \mathrm{~mol} \mathrm{~L}^{-1} \mathrm{HCl}\right)$ & 1 & 90.24 & 7.54 \\
Base hydrolysis $\left(0.5 \mathrm{~mol} \mathrm{~L}^{-1} \mathrm{NaOH}\right)$ & 1 & 88.69 & 9.88 \\
Oxidation $\left(30 \% \mathrm{H}_{2} \mathrm{O}_{2}\right)$ & 4 & 40.08 & 599.70 \\
Thermal $\left(100{ }^{\circ} \mathrm{C}\right)$ & 48 & 99.88 & No degradation \\
Photo & 48 & 99.65 & 999 \\
\hline
\end{tabular}

a Peak purity values in the range of 990-1000 indicate the homogenous peak.

\section{Method validation}

\section{Precision}

Assay of method precision (intra-day precision) was evaluated by carrying out six independent assays of pramipexole test samples against reference standard, the percentage of RSD of six assay values obtained was calculated. The intermediate precision (inter-day precision) of the method was also evaluated using two different analysts, different HPLC systems and different days in the same laboratory (Table 2).

Table 2. Result of precision of test method

\begin{tabular}{lcc}
\hline \multirow{2}{*}{ Sample number } & \multicolumn{2}{c}{ Assay of pramipexole as \% of labeled amount } \\
\cline { 2 - 3 } & $\begin{array}{c}\text { Analyst 1 } \\
\text { (intra-day precision) }\end{array}$ & $\begin{array}{c}\text { Analyst } 2 \\
\text { (inter-day precision) }\end{array}$ \\
\hline 1 & 99.97 & 99.75 \\
2 & 99.87 & 99.40 \\
3 & 99.98 & 99.23 \\
4 & 99.56 & 99.31 \\
6 & 99.45 & 99.43 \\
Mean & 99.68 & 99.13 \\
RSD & 99.75 & 99.45 \\
\hline
\end{tabular}

\section{Accuracy (recovery test)}

Accuracy of the method was studied by recovery experiments. The recovery experiments were performed by adding known amounts of the drugs in the placebo. The recovery was performed at three levels, 80,100 and $120 \%$ of the label claim of the tablet ( $0.25 \mathrm{mg}$ of pramipexole). The recovery samples were prepared in the aforementioned procedure, and then $5 \mathrm{~mL}$ of pramipexole solution were transferred into a $50 \mathrm{~mL}$ volumetric flask and diluted to volume with diluent B. Three samples were prepared for each recovery level. The solutions were then analyzed, and the percentage recoveries were calculated from the calibration curve. The recovery values for pramipexole ranged from 99.87 to $100.03 \%$. The average recoveries of three levels for pramipexole were $99.95 \%$ (Table 3).
Table 3. Results of recovery tests of pramipexole

\begin{tabular}{lccc}
\hline $\begin{array}{l}\text { Level of } \\
\text { addition / }(\%)\end{array}$ & $\begin{array}{c}\text { Amount } \\
\text { added / } \mu \mathrm{g}\end{array}$ & $\begin{array}{c}\text { Recovery / } \\
(\%)\end{array}$ & $\begin{array}{c}\text { Average } \\
\text { recovery / (\%) }\end{array}$ \\
\hline 80 & 16 & 99.96 & \\
100 & 20 & 99.87 & 99.95 \\
120 & 24 & 100.03 & \\
\hline
\end{tabular}

\section{Linearity}

The linearity of the response of the drug was verified at seven concentration levels, ranging from 2.5 to $150 \%$ of the targeted level $\left(20 \mu \mathrm{g} \mathrm{mL}^{-1}\right)$. Concentration standard solutions containing $0.5-30 \mu \mathrm{gL}^{-1}$ of pramipexole in each linearity level were prepared. Linearity solutions were injected in triplicate. The calibration graphs were obtained by plotting peak area versus the concentration data and were treated by least-squares linear regression analysis. The equation of the calibration curve for pramipexole obtained $y=30124 x+5549$, the calibration graphs were found to be linear in the aforementioned concentrations. The coefficient of determination is 0.999 .

\section{Limit of detection and limit of quantification (LOD and $L O Q)$}

The limit of detection (LOD) and limit of quantification (LOQ) were determined by calibration curve method. ${ }^{9}$ Specific calibration curve was constructed using samples containing the analytes in the range of LOD and LOQ. The LOD and LOQ for pramipexole in LC were 0.023 and $0.071 \mu \mathrm{g} \mathrm{mL} \mathrm{m}^{-1}$, respectively. LOD and LOQ were calculated by using the following equations.

$\mathrm{LOD}=3.3 \mathrm{Sa} / \mathrm{b}$ and $\mathrm{LOQ}=10 \mathrm{Sa} / \mathrm{b}$, where $\mathrm{Sa}$ is the standard deviation of the calibration curve and $b$ is the slope of the calibration curve. Precision at limit of quantification and limit of detection was checked by analyzing six test solutions prepared at LOQ and LOD levels and calculating the percentage RSD of area.

\section{Robustness}

To determine the robustness of the developed method experimental condition were purposely altered and the 
resolution between pramipexole dihydrochloride and acid degradation products were evaluated. The flow rate of the mobile phase was $1.0 \mathrm{~mL} \mathrm{~min}^{-1}$. To study the effect of flow rate on the resolution, it was changed by 0.2 units from 0.8 to $1.2 \mathrm{~mL} \mathrm{~min}{ }^{-1}$. The effect of percent organic strength on resolution was studied by varying acetonitrile from -10 to $+10 \%$. The resolution in the robustness study was not less than 3.5 in all conditions. The stability of the standard solutions and the sample solutions was tested at intervals of 24,48 and $72 \mathrm{~h}$. The stability of solutions was determined by comparing results of the assay of the freshly prepared standard solutions. The RSD for the assay results determined up to $72 \mathrm{~h}$ for pramipexole was $0.53 \%$. The assay values were within $1.5 \%$ after $72 \mathrm{~h}$. The results indicate that the solutions were stable for $72 \mathrm{~h}$ at ambient temperature.

\section{Conclusions}

The developed method is stability indicating and can be used for assessing the stability of pramipexole dihydrochloride bulk drugs and pharmaceutical dosage form. The developed method is specific, selective, robust, rugged and precise. This method can be conveniently used for assessing stability assay of selected substances and dissolution of tablets containing pramipexole dihydrochloride in quality control laboratory. The study showed that the drug is stable for the thermal and photo degradation conditions where as moderately degraded in acid (7.54\%) and base (4.88\%) conditions but highly degraded in the oxidative $(58.70 \%)$ conditions.

\section{Acknowledgments}

The authors are thankful to the Head, Department of Chemical Technology, Dr. Babasaheb Ambedkar Marathwada University, Aurangabad - 431004 (MS), India, for providing the laboratory facility.

\section{References}

1. Gottwaldov, M. D.; Bainbridge, J. L.; Dowling, G. A.; Aminoff, M. J.; Alldredge, B. K.; Ann. Pharmacother. 1997, 31, 1205.

2. Cotton, N.; US pat. US2008/0254117 A1 2008.

3. Tripathi, K. D.; Essential of Medical Pharmacology, $5^{\text {th }}$ ed.; Jaypee Brothers Medical Publishers: New Delhi, 2003.

4. http://www.medicalnewstoday.com/articals/56427.php accessed on September 11, 2009.

5. Nirogi, V. S.; Kandikere, V.; Shrivastav, W.; Kotesshwara, M.; Maurya, S.; Aliala, D.; Biomed. Chromatogr. 2007, 21, 1151.

6. Srinubabu, G.; Jaganbabu, K.; Sudharani, B.; Venugopal, K.; Girizasankar, G.; Rao, J.; Chromatographia 2006, 64, 95.

7. Jancic, B.; Madenica, M.; Ivanovic, D.; Chromatographia 2007, $65,633$.

8. Singh, S.; Bakshi, M.; J. Pharm. Biomed. Anal. 2002, 28, 1011.

9. http://private.ich.org/cache/compo/363-272-1.html accessed on September 15, 2009. 